\title{
Discordant monozygotic total colonic Hirschsprung's disease presenting with neonatal isolated ileal perforation
}

\author{
Ramnik V Patel, ${ }^{1,2}$ Suzanne Lawther, ${ }^{3}$ William Alexander Mccallion ${ }^{3}$
}

1 Department of Paediatric Urology, University College London Hospitals NHS Foundation Trust, London, UK ${ }^{2}$ Department of Paediatric Urology, Great Ormond Street Children Hospital NHS Trust, London, UK

${ }^{3}$ Department of Paediatric Surgery, Royal Belfast Hospital for Sick Children, Belfast, UK

\section{Correspondence to} Ramnik V Patel,

ramnik@doctors.org.uk

\section{DESCRIPTION}

A full-term monozygotic twin, one presented with failure to pass meconium at $48 \mathrm{~h}$ of birth, refusal to feeds and abdominal distention. She was unwell with tachycardia and temperature $38.5^{\circ}$ C. Abdomen was distended and tender with absent bowel sounds. She had haemoglobin $75 \mathrm{~g} / \mathrm{L}$, white cell count $20 \times 10^{9} / \mathrm{L}$, neutrophils $10 \times 10^{9} / \mathrm{L}$, platelets $593 \times 10^{9} / \mathrm{L}, \mathrm{C}$ reactive protein $21 \mathrm{mg} / \mathrm{L}$ with normal renal, liver and bone profiles. Abdominal and decubitus radiographs showed pneumoperitoneum (figure 1A, B). She underwent exploratory laparotomy, resection of perforation and primary anastomosis uneventfully and was discharged home after 5 days. She presented with poor feeding, vomiting, no weight gain, irritability, constipation and abdominal distention at 2 weeks of age. Abdominal radiograph was normal with gas in the rectum (figure 1C). Urine cultured Enterobacter cloacae. She was treated with antibiotics, blood transfusion and recovered but had constipation and abdominal distention. Rectal suction biopsy confirmed Hirschsprung's disease; her twin sister was normal. She underwent re-exploration with mapping seromuscular biopsies and frozen section biopsy which showed total colonic Hirschsprung's disease and levelling ileostomy was performed uneventfully. She then underwent modified Duhamel pull through procedure at 1 year of age and is thriving well at 2 months of follow-up. Total colonic Hirschsprung's disease presenting as an isolated terminal ileal perforation in the neonatal period as primary presentation is very rare. ${ }^{12}$ In a term baby with isolated ileal perforation, primary repair is the usual procedure especially when the monozygotic twin was normal. Discordant Hirschsprung's disease in monozygotic twins is very rare. ${ }^{3}$

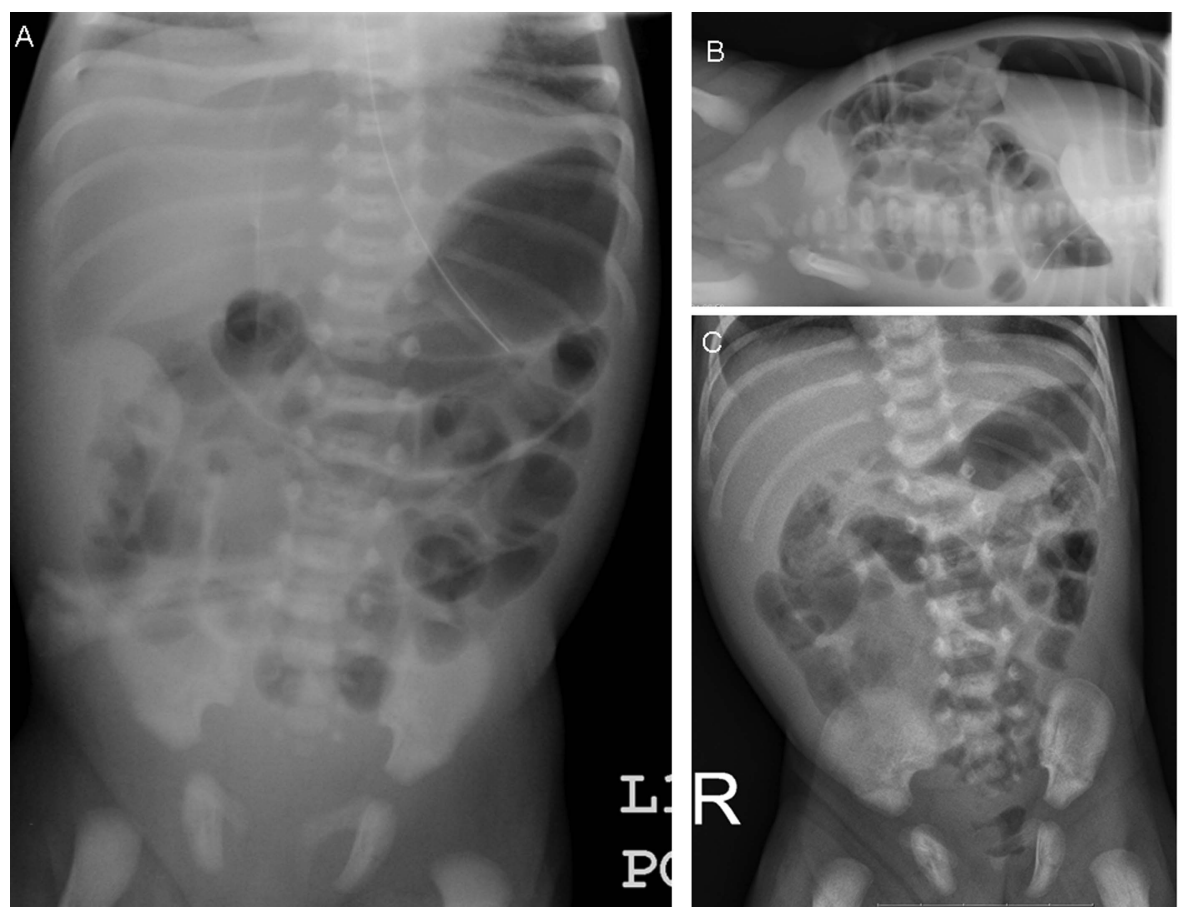

Figure 1 ( $A$ and $B$ ) Abdominal and lateral decubitus radiographs showing normal stomach and upper small bowel obstructive gas pattern and gasless pelvis and peripheral colonic area and massive pneumoperitoneum suggestive of terminal small bowel perforation in the background of obstructive pattern. (C) Abdominal radiograph at re-admission showing normal bowel gas with gas in the rectum. 


\section{Learning points}

- Hirschsprung's disease should present in both identical twins but can present in one of the monozygotic twins as a rare variant and can be missed if the other twin is asymptomatic and well; discordance may lead to confusion and delay in diagnosis.

- In isolated perforation of ileum especially with a transitional zone funnelling appearance of bowel beyond the perforation, index of suspicion for total colonic Hirschsprung's disease should be high.

- If available, frozen section biopsy and levelling ileostomy or mapping seromuscular biopsies and bringing perforation site as stoma may give a correct diagnosis and may help early treatment.
Contributors All authors have been actively involved in the clinical management of this patient and in preparation, editing, appraising and finalising this manuscript.

Competing interests None.

Patient consent Obtained.

Provenance and peer review Not commissioned; externally peer reviewed.

\section{REFERENCES}

1 Newman B, Nussbaum A, Kirkpatrick JA Jr. Bowel perforation in Hirschsprung's disease. AJR Am J Roentgenol 1987;148:1195-7.

2 Stringer MD, Drake DP. Hirschsprung's disease presenting as neonatal gastrointestinal perforation. Br J Surg 1991;78:188-9.

3 Sarioğlu A, Senocak ME, Hiçsönmez A. Discordant Hirschsprung's disease in monozygotic twins with concordant congenital deafness. Eur J Pediatr Surg 2000;10:204-6.

Copyright 2013 BMJ Publishing Group. All rights reserved. For permission to reuse any of this content visit http://group.bmi.com/group/rights-licensing/permissions.

BMJ Case Report Fellows may re-use this article for personal use and teaching without any further permission.

Become a Fellow of BMJ Case Reports today and you can:

- Submit as many cases as you like

- Enjoy fast sympathetic peer review and rapid publication of accepted articles

- Access all the published articles

- Re-use any of the published material for personal use and teaching without further permission

For information on Institutional Fellowships contact consortiasales@bmjgroup.com

Visit casereports.bmj.com for more articles like this and to become a Fellow 